\title{
Relational Thinking of College Students in Solving Recurrence Relation Problems Using Hanoi Tower Props
}

\author{
*Nur Fitriyah Indraswari, Fitriana Minggani \\ Mathematics Education Study Programme, STKIP PGRI Sumenep. Jl. Trunojoyo, \\ Gedungan, Sumenep, Indonesia. Postal code: 69451 \\ *Corresponding Author e-mail: nurfitriyah@stkippgrisumenep.ac.id \\ Received: September 2020; Revised: November 2020; Published: June 2021
}

\begin{abstract}
The purpose of this study is to describe how college students with visual, auditory, and kinaesthetic learning style think relationally in solving recurrence relation problems using the tower of Hanoi. This study is an exploratory with a qualitative descriptive approach. It began by the provision of a mathematics ability test and a learning style questionnaire to obtain three subjects, each of which had a different learning style but equivalent mathematics ability. Next, the three subjects were given problem-solving tasks and interviewed twice. Time triangulation is used to check the consistency of the data. After the validity of the data had been confirmed, the analyses were executed. The data analysis stage of this study consists of five stages: data categorisation, data reduction, data presentation, data interpretation, and conclusion. The result shows that all three subjects met the four indicators of relational thinking, were Understand the problem, make a plan completion, carry out the completion plan, and recheck completion but only the kinaesthetic subject managed to find the final answer.
\end{abstract}

Keywords: relational thinking; recurrence relation; problem-solving; tower of Hanoi

How to Cite: Indraswari, N., \& Minggani, F. (2021). Relational Thinking of College Students in Solving Recurrence Relation Problems Using Hanoi Tower Props. Prisma Sains : Jurnal Pengkajian Ilmu dan Pembelajaran Matematika dan IPA IKIP Mataram, 9(1), 1-11. doi:https://doi.org/10.33394/j-ps.v9i1.2885

\section{INTRODUCTION}

In our life, our every activity is inseparable from an activity called thinking. Thinking is an activity in which the brain processes information which then interprets its ideas effectively to achieve the desired goals. In thinking, the work of the brain is greatly influenced by the information obtained. The thought process carried out by humans is usually due to a cognitive conflict so that it makes humans naturally do it.

Gilmer (in Kuswana, 2011, p.2) states that thinking is a problem-solving and the process of using ideas or symbols to replace an activity that appears physically. Besides, thinking is a cognitive process that gives rise to ideas for solving problems based on (internal or external) information (Sa'o, 2016). This implies that thinking is a cognitive activity in solving a problem using symbols based on existing information.

The thought process that each person has in solving problems is different from one another. Likewise with the college students' relational thinking process in solving recurrence relation problems. Doumas \& Hummel (in Tafrilyanto, 2016) say that relational thinking is the ability to understand analogies between seemingly different objects or events and apply abstract rules in new situations. Also, relational thinking is a fundamental change from previously focusing on arithmetic (calculating answers) to focusing on algebra (examining relationships) (Prayitno, 2015). Relational thinking is a mental process characterized by the arrangement of the linkages between the elements of information provided with prior knowledge and knowledge about the properties or structures of mathematics to solve 
mathematical problems (Santia \& Jatmiko, 2016). Hence, it can be said that relational thinking is a cognitive activity for someone to solve a problem by connecting current knowledge with previous knowledge.

Problem-solving in mathematics is important to be instilled in college students, especially in discrete mathematics courses. Discrete mathematics is one of the compulsory subjects in the mathematics education study program of STKIP PGRI Sumenep which provides a mathematical foundation for other subjects in the mathematics cluster. There are several benefits of studying discrete mathematics, including training abstract thinking, practising logical thinking, and practising problem-solving analysis so that students get used to solving problems critically and rationally (Sugiharni, 2018). Based on Sugiharni's remark, it can be concluded that discrete mathematics is closely related to students' ability to solve problems. But in fact, there are still many college students have difficulty learning discrete mathematics because requires complex calculations (Aminah, 2018). One of the reasons based on Aminah's research, discrete mathematics courses are considered difficult subjects because they require complex calculations

Based on the researcher's experience, many college students have difficulty solving problems in discrete mathematics courses, especially related to the use of symbols and how to operate them. Besides, students also experience difficulties in writing a problem into a mathematical model. This is suitable with the average score of students in Palembang during discrete mathematics learning which is in the low range, which is only around 45.66 (Cahyani, 2019). In discrete mathematics courses, students have difficulty solving story problems so they tend to make mistakes such as reading questions, not understanding questions, how to write answers, and so on (Oktaviana, 2017). One of the reasons why it is difficult to define discrete mathematics is because it contains a large number of mathematical topics in combinatorial, logic, and graphics, including computer science, abstract algebra, number theory, game theory, probability, and geometry (Levin, 2019). Recurrence relations are one of the materials in discrete mathematics courses which are also considered difficult by college students.

Based on the 2015/2016 student response questionnaire to recurrent relation lectures, as many as $49.26 \%$ stated that they were able to understand the material that had been taught, and $25.76 \%$ could apply it in everyday life (Wulandari, 2017). To overcome student difficulties in learning recurrence relations, a teaching aid is needed, one of which is the tower of Hanoi. It is hoped that this visual aid can help students to concretise the abstractness in recurrence relations. The hanoi tower props can be used in learning, including to train students' abilities in solving problems, finding numbers by playing, and finding number pattern formulas (Matematika, 2011). Besides, this teaching aid can help college students to represent a problem into a mathematical model so that they can easily find patterns, make generalisations, and determine the recurrence relation on a problem.

The tower of Hanoi consists of circular plates of different diameters and consists of three columns. The function of the tower of Hanoi is to find the number patterns through playing. The way it is used is: Move the discs from one pole to another with the initial arrangement with the rules: Move only one disc at each transfer and larger discs cannot be placed on smaller discs (Nasaruddin, 2015). In this study, the use of the teaching aid will make it easier for college students to understand the concept and determine the patterns that are formed and solve problems related to recurrence relations. This tower of Hanoi can help students to concrete abstract mathematics so that the researchers can more easily identify students' relational thinking.

The ability of college students in solving a problem, apart from being influenced by relational thinking, is also influenced by learning styles: the way a person absorbs information from outside himself. The way each college student absorbs information differs from one another. Ozgen \& Alkan (2012) consider learning styles as a factor that influences how an individual learns mathematics. Thus, differences in learning styles can lead to 
differences in the construction, understanding, and thinking of a person with information. Therefore, different learning styles will result in different relational thinking. This has an impact on the way they solve recurrence relation problems.

Several studies related to relational thinking include Baiduri (2014) which states that the relational thinking processes of male and female students who have high mathematical abilities when facing math problems have similarities and differences that occur at the elementary school level. Meanwhile, Santia \& Jatmiko (2016) conducted a study related to mathematics learning modules based on students' relational thinking processes which stated that the modules that have been made are suitable for use as teaching materials. In addition, Tafrilyanto (2016) examined the relational thinking profile of high school students in solving math problems in terms of the independent field cognitive style. However, this study is different from the previous studies because it does not only focus on relational thinking processes about math ability, gender, or learning modules. This study focuses more on delineating college students' relational thinking in solving recurrence relation problems using the tower of Hanoi in terms of learning styles. Indicators of relational thinking are adapted from Mirna (2016) and Tafrilyanto (2016).

Based on the explanation of the background above, which essentially states the importance of studying discrete mathematics, there are problems in learning discrete mathematics, especially the material of recurrence relations: the lack of student relational thinking. Because recurrence relations are important and relational thinking is influenced by learning styles, the purpose of this study is to delineate the college students' relational thinking in visual, auditory, and kinaesthetic learning styles in solving recurrence relation problems using the tower of Hanoi.

\section{METHOD}

This study is exploratory because the researcher wants to reveal the information needed for the study. The approach used in this study is descriptive qualitative because it has a natural background and the main instrument of this study is the researcher himself. The analysis was carried out on subjects with auditory, visual and kinaesthetic learning styles about their relational thinking in solving recurrence relation problems using the tower of Hanoi. The time is the even semester of the period 2019/2020. The study began with giving learning style questionnaires to 8 6th-semester college students who had taken discrete mathematics courses. Furthermore, based on the results of the questionnaire, students were grouped according to their respective learning styles. Then the next stage is the provision of a Mathematics Ability Test called Mathematics Ability Test (MAT) of 6 structured which consists of 2 combinatoric questions and 4 generator function questions. After that, 3 college students were taken with the criteria of the same gender, having equal math ability, and each representing a visual, auditory, and kinaesthetic learning style. The next stage was coding. The college student with a visual learning style was coded as SV; the auditory student was coded with SA; the kinaesthetic was coded with SK. Next, the researcher gave a Mathematics Problem-solving Task called Mathematics Problem Solving Tasks (MPST) and then conducted an interview. MPST was given twice in a specific week. The two results from the MPST and the interviews of each college student were tested for their consistency using time triangulation. Based on the triangulation results, MPST 1 and MPST 2 are consistent. Thus, the data is valid and ready to be analyzed. The data analysis stage in this study consisted of 5 phases: data categorisation, data reduction, data presentation, data interpretation, and conclusion. After being analysed, data related to college students' relational thinking in solving recurrence relation problems using the tower of Hanoi was obtained in terms of learning styles.

Data proved to be valid. Thus, the next step is to identify the college students' relational thinking in solving recurrence relation problems using the tower of Hanoi based on indicators 
of relational thinking. The indicators of student relational thinking in solving a recurrence relation problem can be seen in Table 1 .

Table 1. Indicators of College Student Relational Thinking in Solving a Recurrence Relation Problem

\begin{tabular}{|c|c|c|}
\hline $\begin{array}{c}\text { Relational } \\
\text { Thinking Activities }\end{array}$ & $\begin{array}{c}\text { Problem-Solving } \\
\text { Stages }\end{array}$ & Indicators \\
\hline $\begin{array}{l}\text { Building a } \\
\text { relationship } \\
\text { between } \\
\text { information } \\
\text { obtained with prior } \\
\text { knowledge in } \\
\text { understanding the } \\
\text { problem }\end{array}$ & $\begin{array}{l}\text { Understanding the } \\
\text { problem }\end{array}$ & $\begin{array}{l}\text { a. Finding the important elements when } \\
\text { understanding the problem: knowing what } \\
\text { is given and what is asked by question. } \\
\text { b. Building linkages by connecting the } \\
\text { information obtained and prior knowledge } \\
\text { c. Building linkages about the problem as a } \\
\text { whole: connecting what is known and what } \\
\text { is asked to solve the problem }\end{array}$ \\
\hline $\begin{array}{l}\text { Connecting the } \\
\text { information in the } \\
\text { question with prior } \\
\text { knowledge in } \\
\text { making a plan. }\end{array}$ & $\begin{array}{l}\text { Creating } \\
\text { completion plan }\end{array}$ & $\begin{array}{l}\text { a. Building linkages in selecting a completion } \\
\text { strategy: linking known information with } \\
\text { prior knowledge } \\
\text { b. Using symbols, properties, or rules to } \\
\text { produce general terms }\end{array}$ \\
\hline $\begin{array}{l}\text { Linking the } \\
\text { information } \\
\text { obtained from the } \\
\text { question with } \\
\text { previous } \\
\text { knowledge in } \\
\text { implementing the } \\
\text { plan. }\end{array}$ & $\begin{array}{l}\text { Carrying out the } \\
\text { completion plan }\end{array}$ & $\begin{array}{l}\text { Building linkages in the implementation of the } \\
\text { plan: connecting the known information with } \\
\text { prior knowledge }\end{array}$ \\
\hline $\begin{array}{l}\text { Making use of } \\
\text { mathematical } \\
\text { structural relations } \\
\text { in implementing } \\
\text { the plan }\end{array}$ & & $\begin{array}{l}\text { a. Using symbols, concepts, properties, } \\
\text { formulas/rules to solve the problem. } \\
\text { b. Building linkages between unknown } \\
\text { numbers through algebraic operations }\end{array}$ \\
\hline $\begin{array}{l}\text { Linking the } \\
\text { information in the } \\
\text { question with prior } \\
\text { knowledge in } \\
\text { looking back }\end{array}$ & Looking back & $\begin{array}{l}\text { Building linkages when looking back: linking } \\
\text { the known information using arithmetic } \\
\text { operations to determine what is being asked. }\end{array}$ \\
\hline
\end{tabular}

Adapted from Mirna (2016) dan Tafrilyanto (2016)

The following are the problem given to each college student.

\section{$\underline{\text { Problem }}$}

Three poles, A, B, and $\mathrm{C}$ are plugged onto a board. A total of $\mathrm{n}$ discs of different diameters are placed on one of the poles in descending order. an represents the minimum number of steps required to move a tower of $\mathrm{n}$ discs. The discs can be moved to other poles with the following rules.

a. Only one disc can be move at a time.

b. A bigger disc can't be placed on a smaller disc.

Determine:

a) The minimum number of steps required to move 5 discs. Explain how you found it. 
b) Lots of minimum steps to move $\mathrm{n}$ discs. explain the rules that you have created.

c) A recursive relation specifying the minimum number of steps involved in moving $n$ disks.

d) The solution to the recursive relation that you found in point $\mathrm{c}$.

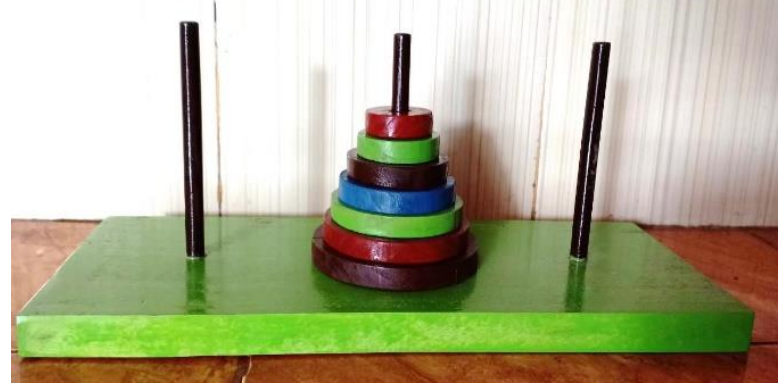

Figure 1. the Tower of Hanoi

\section{RESULTS AND DISCUSSION}

In general, the three research subjects were shocked when they were shown about the tower of Hanoi. They admitted that they had never used the model directly; they had only heard about it. They asked for time to learn the rules for using this model. SV takes about 5 minutes to learn the use of this model, SA takes the longest, which is about 10 minutes. Meanwhile, SK takes the shortest time, which is only 3 minutes. They believed that the minimum number of steps required to move the tower forms a pattern.

\section{Visual Learning Style College Students' Rational Thinking in Solving Recurrence Relation Problems Using the Tower of Hanoi}

Upon receiving the MPST, SV showed a surprised expression. However, in the end, SV realized that MPST was related to the tower of Hanoi. SV could explain what was given from the question and what the question asks clearly. When working, SV seemed to focus on the MPST and the tower of Hanoi. SV notes the minimum number of steps to move one disc to the desired number of discs as a bar chart, can be seen in Figure 2. This is in line with Suhara (2013) which states that visual learning style people think using images in the brain and learns faster. by using visual displays, such as diagrams, images in textbooks, and videos. SV said that the minimum numbers of steps to move the discs from one pole to another one form a number pattern. SV states that the minimum number of steps to move 2 discs has something to do with the minimum number of steps to move 1 disc. Likewise, Likewise, the minimum number of steps to move 4 discs is related to that of 3 discs.

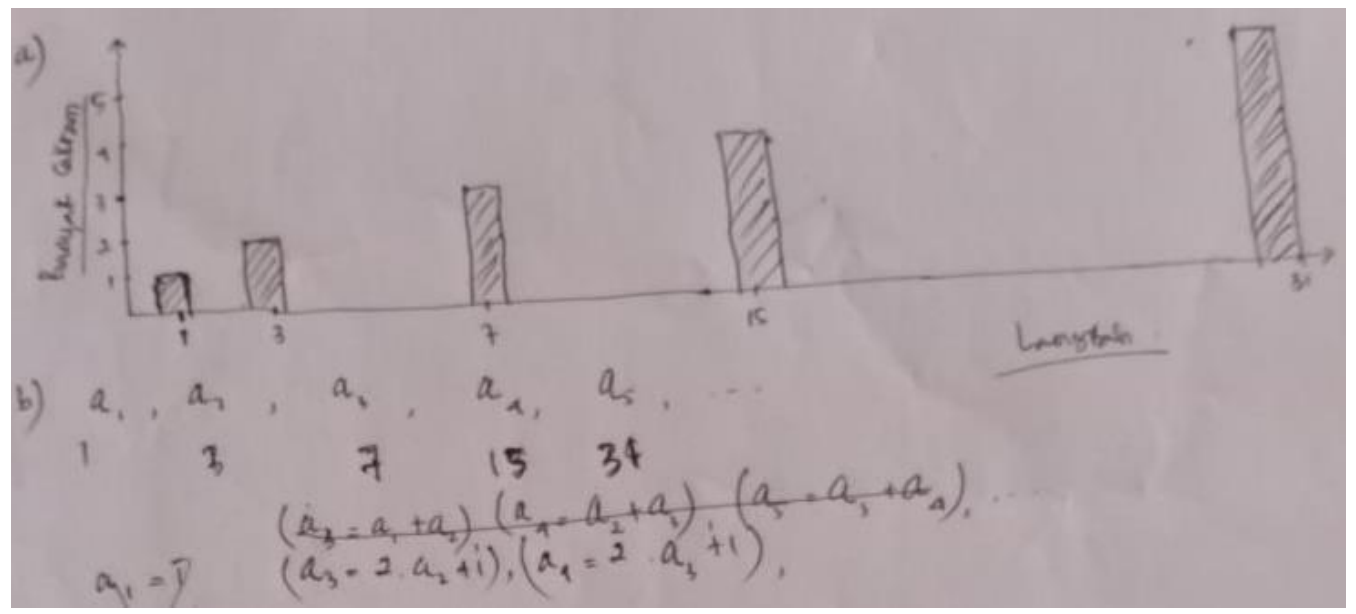

Figure 2. The Work of SV at the Stage of Understanding the Problem and Making a Completion Plan 
At the stage of making the completion plan, SV determines the minimum number of steps to move a disc tower from one pole to another one by looking at the formed pattern. To find the minimum number of steps required to move a tower of 5 discs, SV tried to move from 1 disc to 5 discs. He got a sequence of 1, 3, 7, 15, 31. From here, SV has used mathematical symbols, eg a4 that symbolises the minimum number of steps required to move a tower 4 discs. SV stated $\mathrm{a} 4=2 \mathrm{a} 3+1$ which means the minimum number of steps required to move a tower of 4 discs equals 1 more than twice the minimum number of steps required to move a tower of 3 discs. Then, the researcher asked what if you wanted to find the minimum number of steps required to move a tower of 10 discs. SV said it is the same as the minimum number of steps required to move a tower of 9 discs multiplied by 2 and then added by 1 . This confirms that SV can make rules using symbols.

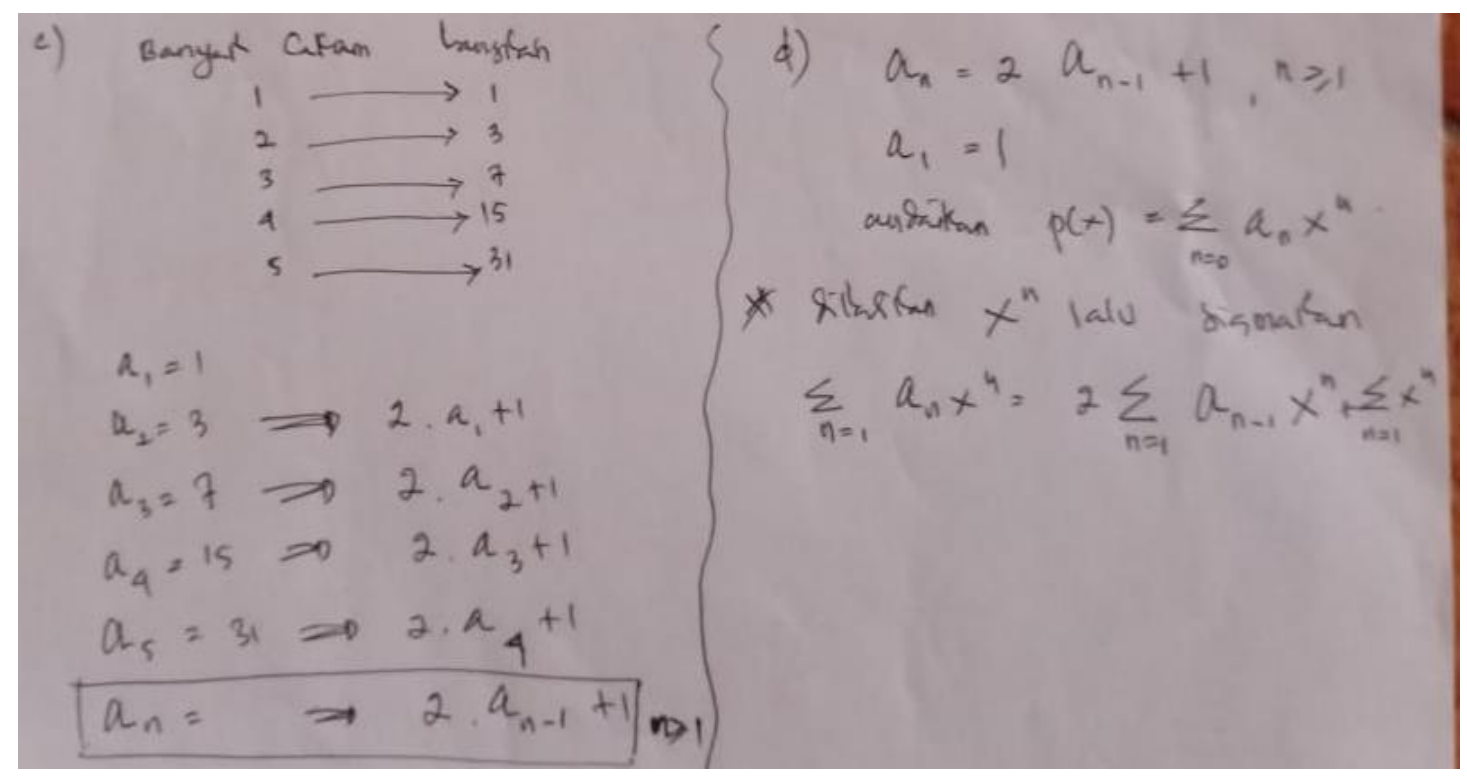

Figure 3. The Work of SV at the Stage of Carrying Out the Completion Plan

At the stage of carrying out the completion plan, SV used the rule that had been found to form the general term of the tower of Hanoi problem. In Figure 3, it is seen that SV wrote the general term of the minimum number of steps required to move $\mathrm{n}$ discs as $2 a_{n-1}+1$, where $n \geq 1$. The general term made is a recurrence relation equipped with its boundary conditions. However, SV hadn't been able to find a solution for the recurrence relations that was created.

At the stage of looking back, SV realised that he could not find the final solution of the recurrence relation. Even so, SV knew that the right method to solve this problem is the generating function. SV stated that to find the final solution of the recurrence relation there are at least 2 methods, the root method and the generating function. SV chose the generating function method because it was easier. SV had difficulties in algebraic operations about symbols such as sigma.

\section{Auditory Learning Style College Students' Rational Thinking in Solving Recurrence Relation Problems Using the Tower of Hanoi}

When given the MPST and the tower of Hanoi, SA was surprised because it was the first time he used the tower of Hanoi. But in the end, SA realised that the tower of Hanoi could help him to solve the problem easier. SA was able to identify the things that were given and asked in detail. During the work, SA was seen repeatedly repeating the same steps and felt confused in operating the model. SA was sometimes confused by the sentence he had said himself and read the questions aloud over and over again. This is in line with Suhara (2013) which states that an auditory learning style person digests the meaning conveyed through the 
toe, voice, pitch (high and low), speaking speed and other auditory matters. SA represented the minimum number of steps required to move from 1 disk to the desired number of discs using a table as shown in Figure 4. SA stated that the minimum number of steps required to move discs and the number of discs affect each other and form a pattern. SA found that to know the minimum number of steps required to move a tower, you must know the minimum number of steps to move the previous tower, which has 1 less disc, and then multiply it by 2 and add by 1 .

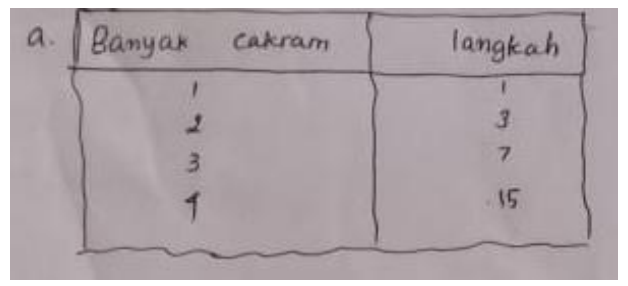

Figure 4. The Work of SA at the Understanding the Problem Stage

At the stage of creating a completion plan, SA stated that to find the minimum number of steps required, the minimum number of steps required to move a tower of 1 disc to that of a tower of the desired number of discs must be found first. It was where SA got the pattern. SA didn't write his work as a sequence, but directly in symbolic form like $a_{3}=15=2 a_{2}+$ 1. SA was able to explain $a_{3}$ stands for the number of steps required to move a tower of 3 discs, can be seen in Figure 5. SA stated that to get the minimum number of steps required to move a tower is equal to twice the minimum number of steps required to move the previous tower added by 1 . At this stage, SA had already produced the general form in terms of $a_{n}$, but no boundary condition $n$ follows. SA considered that without including a limit on the value of $\mathrm{n}$, the general form can still apply. SA didn't realise that the boundary condition for $\mathrm{n}$ is compulsory in a recursive function.

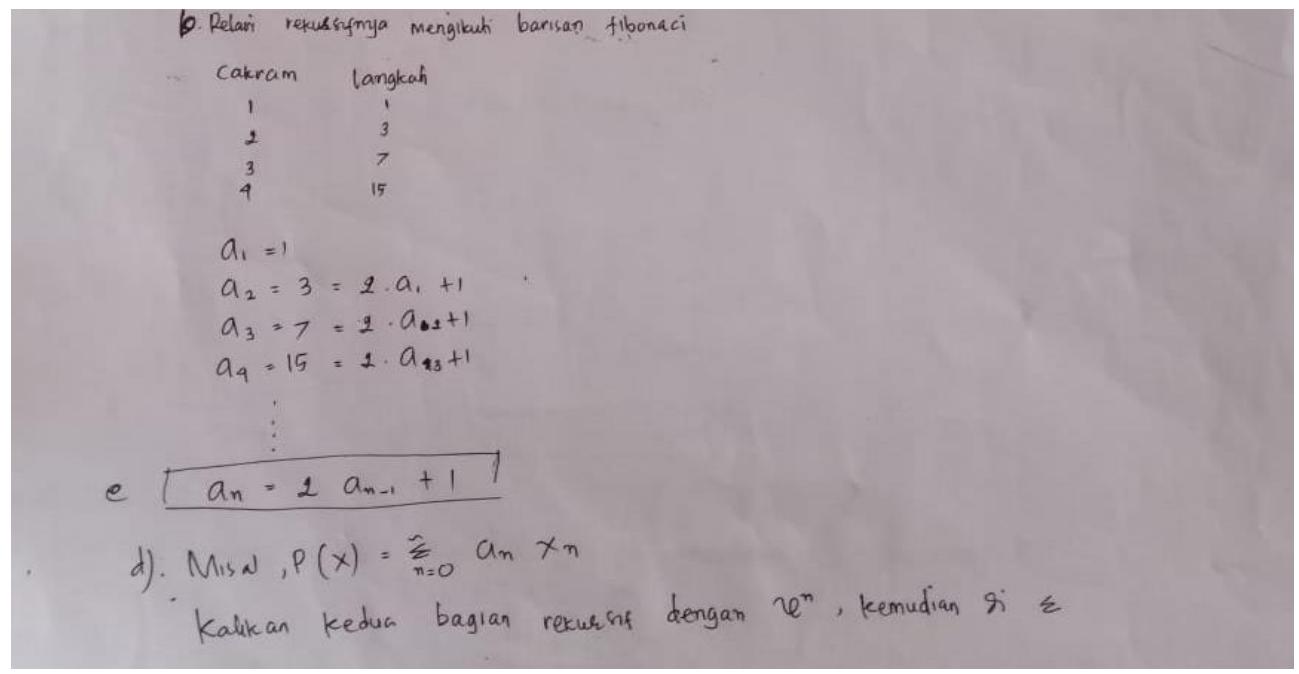

Figure 5. The Work of SA at the Stage of Creating and Carrying Out a Completion Plan

At the stage of carrying out the completion plan, SA used the rules he had found to form a general form of the problem. However, just like SV, SA had not been able to find the final solution. He hadn't even performed the algebraic operations yet.

At the stage of looking back, SA realised that he wasn't able to find the final solution. SA found it difficult to solve as it involves algebraic operations such as sigma which considered difficult to him. However, SA knew the right method to solve this problem is by using the generating function method because the general form obtained is a recurrence relation with a non-homogeneous form. 


\section{Kinaesthetic Learning Style College Students' Rational Thinking in Solving Recurrence Relation Problems Using the Tower of Hanoi}

When given the MPST and the model, SK just smiled. SK admitted that he had known how to use the model even though he had never used it. SK asked for a time to try it. After understanding the problem, Sk realised that there was a connection between MPST and the model provided. SK was able to identify in detail what is given and what is asked by the problem. SK represented the number of steps required to move from 1 disc to the desired number of discs in a table. When working on, SK focused on moving his hands to move the disc from one pole to the others. Occasionally he took notes so that he found the right technique to move the discs without repeating the same steps. This is in line with Suhara (2013) which states that a person with a kinaesthetic learning style prefers to handle, move, touch and feel/experience body movements. SK stated that there is a connection between the number of discs and the minimum number of steps required to move them. Likewise, the minimum numbers of steps required to move the discs form a pattern.

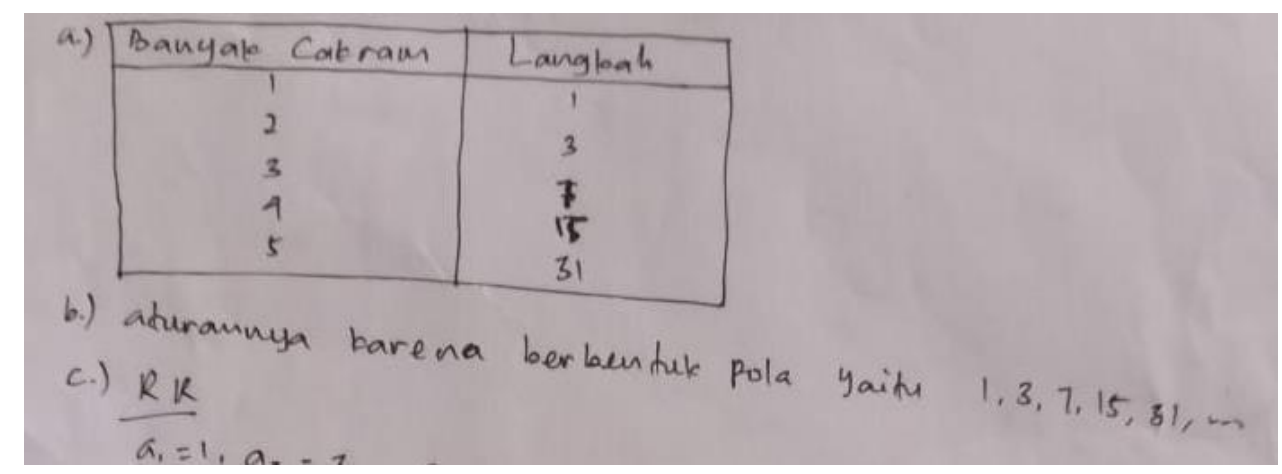

Figure 6. The Work of SK at the Stage of Understanding the Problem and Making the Completion Plan

At the stage of creating a completion plan, SK stated that to determine the minimum number of steps required to move a desired number of discs, he had to try to move consecutively from the tower of 1 disc to the desired number of discs. SK thought that according to the material recurrence relations, what will be discussed is the pattern that is formed, so he tried from the tower of 1 disc to the desired one to find the pattern. SK found that the sequence formed was 1, 3, 7, 15, 31. At this stage, SK had not used symbols to represent the minimum number of steps to move the discs, but when he was being asked about the rules he could answer. SK stated that to move a tower of 5 discs, the method was multiplying the minimum number of steps required to move a tower of 4 discs by 2 times then the result was added by 1 . This indicated that SK had been able to find the rules regarding the given problem.

At the stage of carrying out the completion plan, SK used the rules that have been found previously to create a general form of the minimum number of steps required to move a tower of $\mathrm{n}$ discs using symbols and he stated it in the form of a recurrence relation with the following boundary conditions. SK stated that there is at least one condition that follows a recurrence relation, especially the boundary for $n$ since not all values of $n$ work in the recurrence relation. SK managed to solve the problem until he found the final solution, it can be seen in Figure 7. 


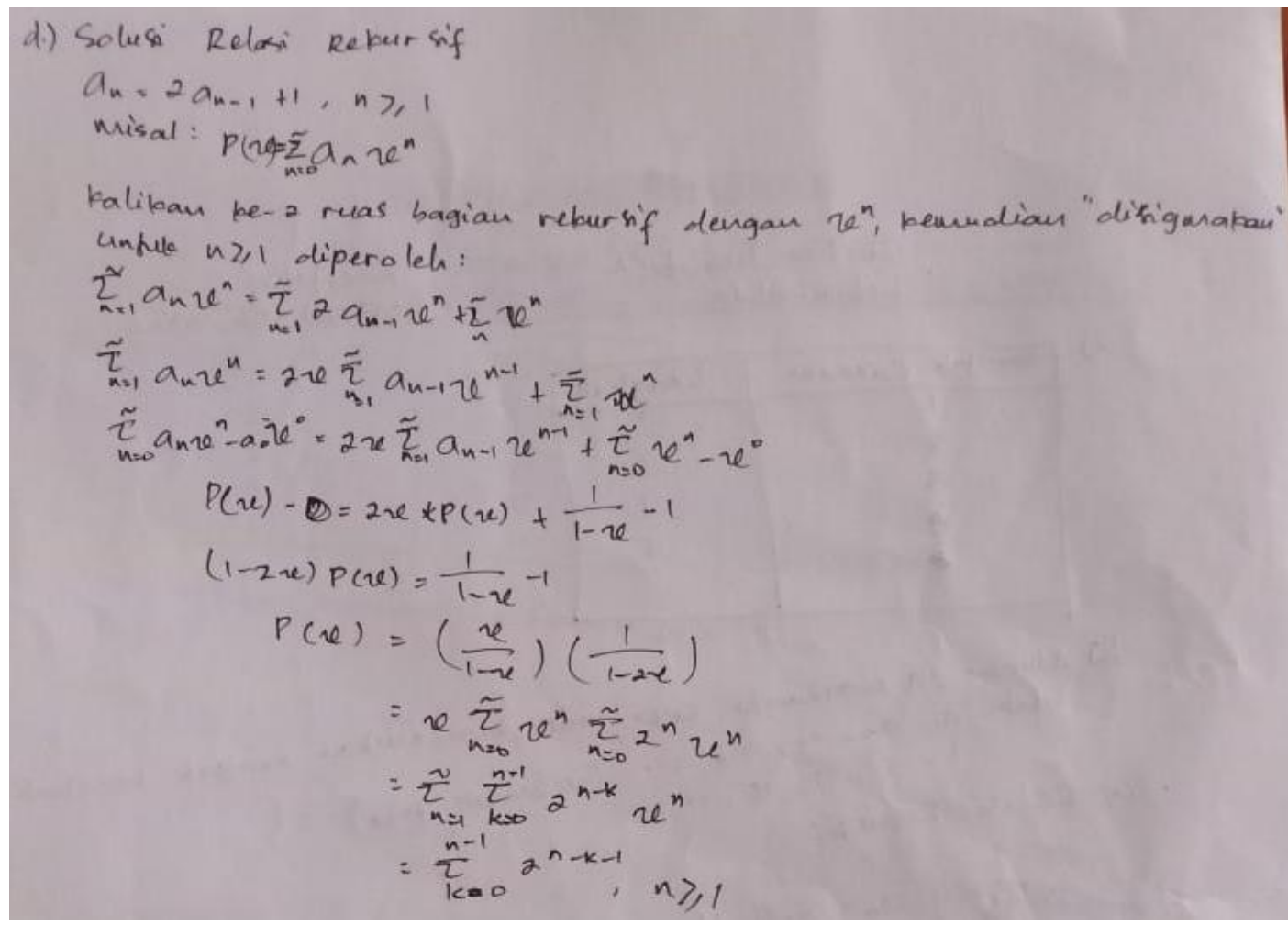

Figure 7. The Work of SK at the Stage of Carrying Out the Completion Plan

At the stage of looking back, Sk had got the correct answer. SK stated that to solve recurrence relations, there are at least 2 methods, the root method and the generating function. The generating function is the method chosen by SK because the recurrence relation formed was non-homogeneous and is easier to work with using the generator function method. When asked step by step, SK was able to explain it in detail. SK solved the problem carefully until he found the final solution. In doing this, he was skilled and mastered the concepts of operation of the generator function which contained the sigma notation.

\section{CONCLUSION}

All of the three subjects were able to use the tower of Hanoi properly, but SA took longer because there were several steps repeated. At the stage of understanding the problem, the three college students were able to understand the problem which was related to the use of the tower of Hanoi. At the stage of making a completion plan, the three subjects were able to discover the regularity of the patterns formed from the relationship between the number of discs and the minimum number of steps required. At the stage of carrying out the completion plan, the three subjects had used symbols, but only the college student with the kinesthetic learning style wrote them directly in the form of recurrence relations equipped with the following conditions. At the stage of carrying out the completion plan, the three subjects chose the same method in determining the solution: the generating function method. At the looking-back stage. Among the three students, only the student with the kinesthetic learning style was able to solve the recurrence relations until the final solution. SV and SK found it difficult to operate algebra which involves various symbols, one of which is sigma.

\section{RECOMMENDATION}

Based on the results of the study, it indicates that the use of Hanoi tower props can make it easier for students to understand recursive relationships. In addition, students' relational thinking in kinesthetic learning styles is relatively better than students in visual and auditory learning styles. Therefore, it is necessary to have further research related to the level of student relational thinking and how to effectively train students to think relational. 


\section{ACKNOWLEDGMENT}

Researchers would like to thank Ristekdikti for providing research grants for beginner lecturers for the 2020 fiscal year to researchers. In addition, the researchers also expressed their gratitude to STKIP PGRI Sumenep, especially the mathematics education study program which has provided support and facilities in completing this study.

\section{REFERENCES}

Aminah, S. (2018). Pengaruh Pembelajaran Matematika Diskrit dengan Blended Learning Terhadap HAsil Belajar. MUST: Journal of Mathematics Educaion, Science and Technology, 3(1), 22-32.

Baiduri. (2014). A Relational Thinking Process of Elementery School Students with High Capability. Journal of Educational and Developmental Psychology, 4(2), 24-34. https://doi.org/10.5539/jedp.v4n2p24

Cahyani, L. (2019). Analisis Kesulitan Belajar Matematika Diskrit pada Mahasiswa Manajemen Informatika Amik Bina Sriwijaya Palembang. In Prosiding Seminar Nasional Pendidikan Program Pascasarjana Universitas PGRI Palembang (pp. 430442). Palembang: Universitas PGRI Palembang.

Levin, O. (2019). Discrete Mathematics An Open Introduction (3RD Editio). Greeley: School of Mathematical Science, University of Northern Colorado.

Matematika, T. U. M. A. P. (2011). Alat Peraga Menara Hanoi untuk Pembelajaran Pola Bilangan. In Alat Peraga (pp. 1-7). Tim Unit Media Alat Peraga Matematika.

Nasaruddin. (2015). Media dan Alat Peraga dalam Pembelajaran Matematika. Al-Khwarizmi, III (2), 21-30.

Oktaviana, D. (2017). Analisis Tipe Kesalahan Berdasarkan Teori Newman dalam Menyelesaikan Soal Cerita pada Mata Kuliah Matematika Diskrit. EduSains: Jurnal Pendidikan Sains \& Matematika, 5(2), 22-32.

Ozgen, K., \& Alkan, H. (2012). The Relationship between Secondary School Pre-Service Mathematics Teachers' Skills in Problem Solving Dimensions and Their Learning Style Characteristics. Educational Sciences: Theory and Practice, 12(2), 1173-1181. Retrieved from http://www.eric.ed.gov/ERICWebPortal/recordDetail?accno=EJ981835

Prayitno, A. (2015). Proses Berpikir Refraksi Siswa dalam Menyelesaikan Masalah Matematika Tentang Kesamaan. LIKITHAPRADNYA, 17(1 (April 2015)), 25-37.

Sa'o, S. (2016). Berpikir Intuitif Sebagai Solusi Mengatasi Rendahnya Prestasi Belajar Matematika. Jurnal Review Pembelajaran Matematika, 1(1), 43-56. https://doi.org/https://doi.org/10.15642/jrpm.2016.1.1.43-56

Santia, I., \& Jatmiko. (2016). Santia dan Jatmiko,. Jurnal Math Educator Nusantara, 2(1), 11-18. Retrieved from http://ojs.unpkediri.ac.id/index.php/matematika/article/view/394

Sugiharni, G. A. D. (2018). Pengembangan Modul Matematika Diskrit Berbentuk Digital dengan Pola Pendistribusian Asynchronous Menggunakan Teknologi Open Source. Jurnal Nasional Pendidikan Teknik Informatika (JANAPATI), 7(1 (Maret 2018)), 58-72.

Suhara, A. M. (2013). Keefektifan Model Vak (Visualization Auditory Kinestetic) Dalam Pembelajaran Menulis Deskriptif (Studi Eksperimen Pada Siswa Kelas X SMA Negeri 1 Lawang Kidul,Sumatera Selatan) Universitas Pendidikan Indonesia | repository.upi.edu (pp. 285-309). Bandung: Universitas Pendidikan Indonesia. Retrieved from repository.upi.edu

Tafrilyanto, C. F. (2016). Profil Berpikir Relasional Siswa SMA dalam Pemecahan Masalah 
Matematika Ditinjau dari Gaya Kognitif Field Independent. In Prosiding Seminar Nasional Pendidikan Matematika "Peran Matematika dan Pembelajarannya dalam Mengembangkan Kearifan Budaya Lokal untuk M (pp. 105-114). Pamekasan: , Prodi Pendidikan Matematika, FKIP Universitas Madura.

Wulandari, A. A. (2017). Implementasi Worksheet ELPSA Pada Pembelajaran Relasi Rekurensi Implementation of ELPSA Worksheets on Recurrence Relation Learning. JIPM (Jurnal Ilmiah Pendidikan Matematika), 6(1), 60-67. Retrieved from http://journal.unipma.ac.id/index.php/jipm JIPM 